\title{
Pengembangan Komoditas Pertanian Unggulan di Wilayah Perbatasan Bengkayang Mendukung Pengembangan Lumbung Pangan
}

\author{
Development of Leading Agricultural Commodities in Bengkayang \\ Border Region Supporting Development of Food Barn
}

\section{Joko Mulyono ${ }^{1}$}

Diterima: 5 Maret 2019 Disetujui: 18 Juni 2019

\begin{abstract}
Abstrak: Produktivitas pertanian di wilayah perbatasan Kabupaten Bengkayang rendah, di satu sisi luas lahan pertanian cukup luas $(89,23 \%)$ ditambah dengan tingkat kepadatan penduduk yang hanya $44 \mathrm{jiwa} / \mathrm{km}^{2}$. Tujuan penelitian adalah untuk menentukan komoditas pertanian unggulan di wilayah perbatasan Kabupaten Bengkayang, Provinsi Kalimantan Barat mendukung pengembangan lumbung pangan nasional. Penelitian ini menggunakan data sekunder meliputi data luas panen tanaman pangan, produksi tanaman hortikultura, produksi tanaman perkebunan, dan populasi ternak tahun 2011-2015 yang diperoleh dari Badan Pusat Statistik (BPS) Kabupaten Bengkayang, Kalimantan Barat. Data tersebut dianalisis dengan analisis Location Quotient (LQ) dan Shift Share Analysis (SSA). Hasil penelitian menunjukkan bahwa kelapa sawit menjadi komoditas unggulan perkebunan di wilayah perbatasan Kecamatan Jagoi Babang dan lada di Kecamatan Siding. Sapi, babi, dan itik menjadi komoditas unggulan peternakan di wilayah perbatasan Kecamatan Jagoi Babang dan itik di Kecamatan Siding.
\end{abstract}

Kata kunci: pengembangan, komoditas unggulan, perbatasan

\begin{abstract}
Agricultural productivity in the border region of Bengkayang Regency is low, on one side the area of agricultural land is quite extensive $(89.23 \%)$ coupled with a population density of only 44 people $/ \mathrm{km}^{2}$. The research objective was to determine the leading agricultural commodities in the border region of Bengkayang Regency, West Kalimantan Province to support the development of a national food barn. This study uses secondary data covering data on crops harvest area, horticulture crop production, plantation production, and livestock populations in 2011-2015 obtained from the Bengkayang Regency Central Statistics Agency (BPS), West Kalimantan. The data is analyzed by analysis of Location Quotient (LQ) and Shift Share Analysis (SSA). The results of the study showed that oil palm was the plantation's leading commodities in the border region of Jagoi Babang Subdistrict and pepper in Siding SubDistrict. Cows, pigs, and ducks are the leading commodities of livestock in the border region of Jagoi Babang Subdistrict and ducks in Siding Subdistrict.
\end{abstract}

Keywords: development, leading commodities, border

\footnotetext{
${ }^{1}$ Balai Besar Pengkajian dan Pengembangan Teknologi Pertanian
} 


\section{PENDAHULUAN}

Wilayah perbatasan Kabupaten Bengkayang, Kalimantan Barat memiliki peran yang cukup strategis dilihat dari berbagai aspek meliputi aspek ekonomi, sosial, budaya dan pertahanan keamanan. Secara geografis, wilayah perbatasan Kabupaten Bengkayang memiliki perbatasan wilayah dengan negara tetangga Malaysia, yaitu di sebelah utara tepatnya dengan Serawak. Luas wilayah Kabupaten Bengkayang 5.396,30 km², dengan tingkat kepadatan penduduknya 44 jiwa $/ \mathrm{km}^{2}$ (BPS Kabupaten Bengkayang, 2016).

Aksesibilitas dan sarana prasarana di wilayah perbatasan Kabupaten Bengkayang, Kalimantan Barat masih kurang memadai dibanding dengan wilayah lainnya di luar wilayah perbatasan. Selain itu, permasalahan lainnya adalah keterbatasan sumber daya manusia yang disebabkan rendahnya pendidikan dan kesehatan. Menurut (Raharjo, 2013), permasalahan utama di wilayah perbatasan adalah kurangnya infrastruktur dan rendahnya pendidikan. Hal ini didukung oleh penelitian (Priyanto \& Diwyanto, 2014), bahwa masalah di wilayah perbatasan adalah keterisolasian, ketertinggalan, kemiskinan, dan keterbatasan sarana dan prasarana pelayanan publik, terutama infrastruktur fisik dan kelembagaan. Pembangunan di wilayah perbatasan masih tertinggal dibandingkan dengan wilayah lainnya, hal ini diperkuat oleh penelitian (Putra, 2015), bahwa ada kesenjangan (disparity) pembangunan antara wilayah perbatasan dengan wilayah lain di luar perbatasan.

Sektor pertanian masih menjadi penyumbang utama pendapatan di wilayah perbatasan Kabupaten Bengkayang yang mencapai 33,89\%. Selain itu, sektor pertanian menjadi sumber mata pencaharian utama penduduk di perdesaan. Penduduk di wilayah perbatasan Bengkayang sebagian besar bekerja di sektor pertanian $(73,83 \%)$, di samping bekerja di sektor lainnya seperti sektor jasa $(9,13 \%)$ sektor perdagangan $(8,99 \%)$, industri $(2,56 \%)$, pertambangan $(2,09 \%)$, konstruksi $(1,21)$, transportasi $(1,19 \%)$, lembaga keuangan (0,69\%), dan sektor listrik, gas dan air minum (0,30\%) (BPS Kabupaten Bengkayang, 2016). Di samping itu, sektor pertanian juga menghasilkan bahan makanan. Menurut (Mulyono \& Munibah, 2016b), sektor pertanian berperan dalam menyerap tenaga kerja, menciptakan lapangan pekerjaan, mengurangi pengangguran dan kemiskinan, serta menyediakan tenaga kerja dan pangan.

Potensi sektor pertanian di wilayah perbatasan Bengkayang dapat dioptimalkan sesuai dengan sumberdaya yang dimiliki, dimana lahan pertanian tersedia cukup luas. Luas lahan pertanian 481.215 ha $(89,23 \%)$ terdiri dari lahan sawah 34.835 ha dan lahan bukan sawah 446.677 ha. Untuk lahan bukan sawah terdiri dari lahan tegal/kebun 41.283 ha, ladang/huma 20.582 ha, perkebunan 142.835 ha, dan lainnya 241.977 ha. Menurut (Gabriel, Nurcahyo, Muslim, \& Sumaedi, 2016), sektor pertanian menjadi sektor unggulan di Kabupaten Bengkayang karena sektor tersebut diusahakan di seluruh kecamatan di Kabupaten Bengkayang dengan lahan yang luas dan terus dikembangkan menjadi komoditas unggulan.

Komoditas pertanian yang dikembangkan cukup beragam, mulai dari tanaman pangan, hortikulura, perkebunan, dan peternakan, tetapi produktivitasnya masih rendah. Menurut (Kementerian Pertanian Republik Indonesia, 2017), produktivitas pangan dan efisiensi sistem produksi di sebagian besar wilayah perbatasan masih rendah akibat keterbatasan infrastruktur, lambatnya penerapan inovasi pertanian, dan terbatasnya SDM. Dalam kurun waktu 4 tahun terakhir (2012-2015), produktivitas padi sawah terus mengalami penurunan. Pada tahun 2015 produktivitas padi sawah 2,76 ton/ha, sedangkan pada tahun 2014 produktivitasnya 3,68 ton/ha, pada tahun 2013 sebesar 4,02 ton/ha, dan tahun 2012 sebesar 4,09 ton/ha. Produktivitas padi ladang tahun 2015 sebesar 1,88 ton/ha lebih rendah dibandingkan tahun 2014 sebesar 1,95 ton/ha, produktivitas padi ladang tahun 2013 sebesar 2,22 ton/ha, dan tahun 2012 sebesar 2,36 ton/ha. Hal ini juga terjadi pada komoditas tanaman pangan lainnya seperti jagung, kedelai, dan kacang hijau.

Beranjak dari masalah, kendala dan potensi di wilayah perbatasan, pengembangan komoditas pertanian harus difokuskan pada komoditas unggulan sesuai dengan 
sumberdaya yang dimiliki wilayahnya. Pengembangan lumbung pangan di wilayah perbatasan harus mempertimbangkan dan fokus pada daya saing komoditas melalui tiga pendekatan: efisiensi produksi, pemilihan jenis komoditas, dan peningkatan mutu hasil melalui pengembangan sistem pertanian intensif dan modern (Kementerian Pertanian Republik Indonesia, 2017). Penelitian ini bertujuan untuk menentukan komoditas pertanian unggulan di wilayah perbatasan Kabupaten Bengkayang, Provinsi Kalimantan Barat mendukung pengembangan lumbung pangan nasional.

\section{METODE PENELITIAN}

Penelitian ini merupakan penelitian studi kasus di Kabupaten Bengkayang, Kalimantan Barat yang merupakan wilayah perbatasan yang berbatasan dengan negara tetangga, Malaysia. Wilayah perbatasan saat ini menjadi program prioritas pemerintah yang dituangkan dalam Nawacita, yaitu membangun Indonesia dari pinggiran dengan memperkuat daerah-daerah dan desa untuk meningkatkan produktivitas dan daya saing, serta mewujudkan kemandirian ekonomi dengan menggerakkan sektor-sektor strategis. Penelitian ini menggunakan data sekunder, meliputi data luas lahan pertanian, luas panen tanaman pangan, produksi tanaman hortikultura, produksi tanaman perkebunan, dan populasi ternak Kabupaten Bengkayang dari tahun 2011-2015. Data tersebut diperoleh dari Badan Pusat Statistik (BPS) Kabupaten Bengkayang, Kalimantan Barat.

Penentuan komoditas pertanian unggulan di wilayah perbatasan menggunakan analisis Location Quotient (LQ) dan Shift Share Analysis (SSA). Dalam penelitian ini, suatu komoditas menjadi komoditas unggulan di suatu wilayah atau kecamatan apabila nilai LQ $>1$ dan nilai SSA positif. Makna nilai LQ $>1$ dan nilai SSA positif adalah bahwa produksi komoditas pada wilayah atau kecamatan tersebut mampu memenuhi kebutuhaan di wilayahnya dan di luar wilayahnya, serta produksi komoditas tersebut selalu mengalami pertumbuhan. (Mulyono \& Munibah, 2016a), menggunakan analisis LQ, SSA dan peta pewilayahan komoditas pertanian berdasarkan zona agroekologi untuk menentukan komoditas unggulan sub sektor tanaman pangan. Sedangkan (Sukmawani, Haeruman, Sulistyowati, \& Perdana, 2014) menggunakan analisis LQ, analisis berdasarkan kriteria unggul dan analisis daya saing dalam melakukan penelitian model pengembangan komoditas pepaya sebagai komoditas unggulan lokal yang berdaya saing.

Analisis Location Quotient (LQ) dirumuskan sebagai berikut:

dimana:

$$
\mathrm{LQ}=\frac{\mathrm{pi} / \mathrm{pt}}{\mathrm{Pi} / \mathrm{pt}}
$$

$\mathrm{p}_{\mathrm{i}}:$ luas areal panen/produksi/populasi komoditas i pada tingkat kecamatan

$\mathrm{p}_{\mathrm{t}}$ : total luas areal panenproduksi/populasi semua komoditas pada tingkat kecamatan

$\mathrm{P}_{\mathrm{i}}$ : total luas areal panen/produksi/populasi komoditas i pada tingkat kabupaten

$\mathrm{P}_{\mathrm{t}}$ : luas areal panen/produksi/populasi komoditas total pada tingkat kabupaten

Analisis Shift Share Analysis (SSA) dirumuskan sebagai berikut:

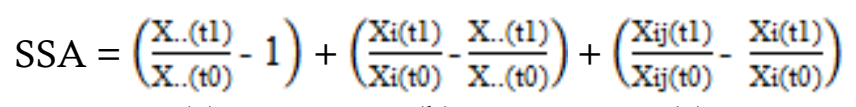

(a)

(b)

dimana:

\footnotetext{
a : komponen regional share

b : komponen proportional shift

c : komponen differential shift
} 
$X_{\text {.. }}$ : nilai total aktivitas dalam total wilayah

$\mathrm{X}_{\mathrm{i}}$ : nilai total aktivitas tertentu dalam total wilayah

$\mathrm{X}_{\mathrm{ij}}$ : nilai aktivitas tertentu dalam unit wilayah tertentu

$\mathrm{t}_{1} \quad$ : titik tahun terakhir

$\mathrm{t}_{0} \quad$ : titik tahun awal

\section{HASIL DAN PEMBAHASAN}

\section{Sumber Daya Lahan Pertanian Wilayah Perbatasan Kabupaten Bengkayang}

Kabupaten Bengkayang merupakan salah satu kabupaten di Kalimantan Barat yang merupakan wilayah perbatasan, memiliki 17 kecamatan, yaitu: Kecamatan Sungai Raya, Capkala, Sungai Raya Kepulauan, Samalantan, Monterado, Lembah Bawang, Bengkayang, Teriak, Sungai Betung, Ledo, Suti Semarang, Lumar, Sanggau Ledo, Tujuh Belas, Seluas, Jagoi Babang, dan Siding. Kecamatan Jagoi Babang dan Siding merupakan kecamatan yang berbatasan langsung dengan Negara Malaysia, yaitu Serawak.

Bagi rumah tangga petani, lahan menjadi aset utama dalam melakukan usahatani (Mulyono, Hadi, \& Munibah, 2016). Menurut (Koirala, Mishra, \& Mohanty, 2016), lahan merupakan faktor kunci dalam produksi pertanian dan kepemilikan lahan memiliki dampak signifikan pada efisiensi teknis. Lahan pertanian terdiri dari lahan sawah dan lahan bukan sawah. Luas lahan pertanian Kabupaten Bengkayang, Kalimantan Barat 481.512 ha $(89,82 \%)$. Lahan pertanian tersebut didominasi lahan bukan sawah $92,77 \%$ (446.677 ha), sedangkan lahan sawah berkisar 7,23\% (34.835 ha). Lahan bukan sawah merupakan lahan kering terdiri dari lahan tegalan, ladang, perkebunan, dan lainnya yang mengandalkan curah hujan dalam pemanfaatannya. Menurut (Mulyani \& Sarwani, 2013), lahan kering di Kalimantan Barat mencapai 11.504.524 ha terdiri dari lahan kering masam 11.483.416 ha dan lahan kering iklim kering 21.108 ha. Apabila lahan dirinci lebih lanjut, luas lahan sawah 6,46\%, lahan tegal/kebun 7,65\%, lahan ladang/huma 3,81\% lahan perkebunan $26,47 \%$, lahan lainnya (hutan rakyat, padang rumput, hutan negara, sementara tak diusahakan, lainnya) 44,84\%, dan lahan bukan pertanian 10,77\%.

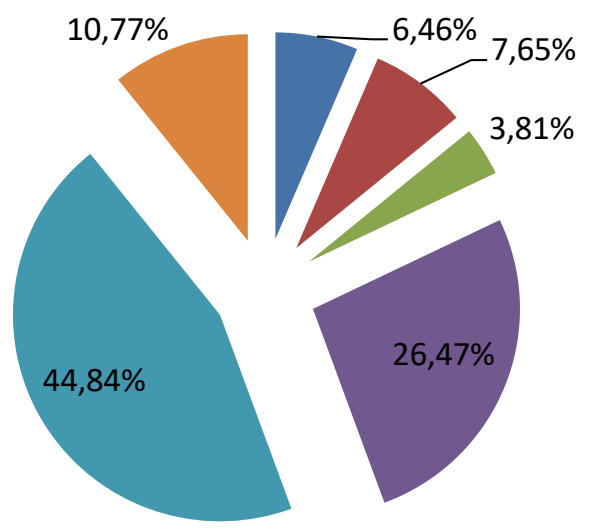

$$
\begin{aligned}
& \text { - lahan sawah } \\
& \text { - lahan tegal/kebun } \\
& \text { - lahan ladang/huma } \\
& \text { - lahan perkebunan } \\
& \text { - lahan lainnya } \\
& \text { - Lahan bukan Pertanian }
\end{aligned}
$$

\section{Gambar 1. Luas Lahan Wilayah Perbatasan Kabupaten Bengkayang, Kalbar}

Berangkat dari potensi luas lahan yang dimiliki, Kabupaten Bengkayang yang merupakan wilayah perbatasan memiliki peluang peningkatan produksi komoditas pertanian. Peningkatan produksi pertanian dilakukan melalui penerapan inovasi, sehingga dapat mendukung pengembangan lumbung pangan di wilayah perbatasan. Peningkatan 
produksi pertanian dapat dilakukan di lahan sawah maupun lahan bukan sawah (lahan kering). Peningkatan produksi di lahan sawah memiliki kendala dan tantangan yang lebih ringan dibandingkan pada lahan kering. Hal ini disebabkan karena aksesibilitas dan infrastruktur di lahan sawah lebih baik dibandingkan di lahan kering, ditambah topografi lahan sawah relatif lebih datar dibandingkan lahan kering.

Meskipun kendala dan tantangan peningkatan produksi pertanian pada lahan kering lebih berat dibandingkan lahan sawah, tetapi dengan penerapan teknologi yang tepat produktivitasnya dapat ditingkatkan. Menurut (Abdurahman, Dariah, \& Mulyani, 2008), teknologi pengelolaan lahan kering telah tersedia, namun pemanfaatan lahan kering untuk pertanian sering diabaikan, padahal lahan kering tersedia cukup luas dan berpotensi menghasilkan padi gogo $>5$ ton/ha. Di samping menghasilkan beras, lahan kering juga menghasilkan bahan pangan lainnya seperti jagung, sorghum, kedelai, kacang hijau, ubi kayu, dan ubi jalar.

\section{Sumber Daya Manusia Wilayah Perbatasan Kabupaten Bengkayang}

Pada tahun 2015 penduduk Kabupaten Bengkayang berjumlah 238.610 jiwa, terdiri atas 123.784 jiwa laki-laki dan 114.736 jiwa perempuan dan tersebar di 17 kecamatan. Laju pertumbuhan penduduk 2,01\%, sedangkan tingkat kepadatan penduduknya $44 \mathrm{jiwa} / \mathrm{km}^{2}$. Menurut (Kementerian Pertanian Republik Indonesia, 2017), wilayah perbatasan dicirikan oleh tingkat kepadatan penduduk yang rendah dan tidak merata dengan arela yang relative luas.

Jumlah penduduk yang besar berfungsi sebagai tenaga kerja, dimana pada sektor pertanian berperan sebagai tenaga kerja dari hulu sampai hilir. Di sisi lain, pertumbuhan penduduk yang terus meningkat menyebabkan konsumsi pangan meningkat. Seiring dengan pertumbuhan penduduk tersebut, perlu diikuti oleh peningkatan produksi pangan. Kebutuhan pangan senantiasa meningkat seiring dengan peningkatan jumlah penduduk (Purwaningsih, 2008).

Penduduk Kabupaten Bengkayang termasuk dalam usia produktif (64,5\%). Sebagian besar penduduk di wilayah perbatasan Kabupaten Bengkayang, Kalimantan Barat bekerja di sektor pertanian mencapai $73,83 \%$, sedangkan yang bekerja di sektor lainnya seperti sektor industri, perdagangan, jasa, bangunan dan lainnya mencapai $26,17 \%$.

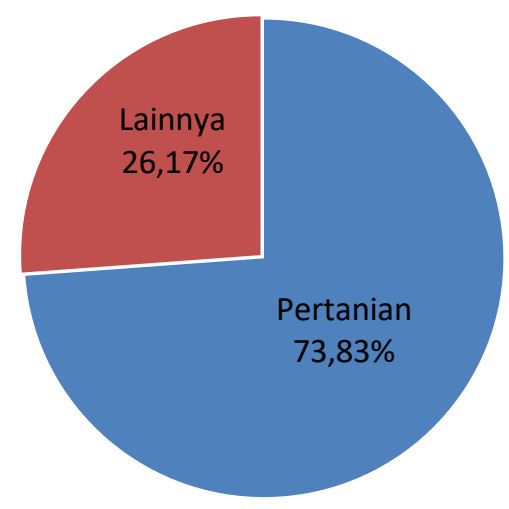

Gambar 2. Pekerjaan Utama Penduduk Wilayah Perbatasan Kabupaten Bengkayang, Kalbar 


\section{Komoditas Pertanian Unggulan Wilayah Perbatasan Kabupaten Bengkayang}

Komoditas pertanian yang dibudidayakan di wilayah perbatasan Kabupaten Bengkayang cukup beragam, seperti padi, jagung, kedelai, kacang panjang, cabe, ketimun, pepaya, pisang, durian, langsat/kokosan, karet, lada, kakao, sapi, kambing, ayam, dan sebagainya. Komoditas unggulan pertanian dikelompokkan menjadi 4 kelompok, yaitu tanaman pangan, hortikultura (sayuran dan buah-buahan), perkebunan, dan perternakan.

Dari analisis LQ dan SSA, masing-masing kelompok tersebut diperoleh komoditas unggulan wilayahnya. Pengembangan komoditas pertanian harus diprioritaskan pada komoditas unggulan berdasarkan sumberdaya yang dimiliki wilayahnya. Produktivitas komoditas unggulan tersebut dapat ditingkatkan melalui penerapan teknologi, sehingga dapat meningkatkan produksi dan daya saingnya. Berdasarkan analisis LQ dan SSA, komoditas pertanian unggulan wilayah perbatasan Kabupaten Bengkayang disajikan pada Tabel 1.

Tabel 1.Komoditas Pertanian Unggulan Wilayah Perbatasan Bengkayang

\begin{tabular}{|c|c|c|c|c|c|}
\hline \multirow{3}{*}{ Kecamatan } & \multicolumn{5}{|c|}{ Komoditas Pertanian Unggulan } \\
\hline & \multirow{2}{*}{$\begin{array}{c}\text { Tanaman } \\
\text { pangan }\end{array}$} & \multicolumn{2}{|c|}{ Hortikultura } & \multirow{2}{*}{ Perkebunan } & \multirow{2}{*}{ Peternakan } \\
\hline & & Sayuran & Buah-Buahan & & \\
\hline Sungai Raya & Kedelai & $\begin{array}{l}\text { Kacang } \\
\text { panjang, cabe } \\
\text { besar, terong, } \\
\text { ketimun, } \\
\text { semangka }\end{array}$ & $\begin{array}{l}\text { Jeruk } \\
\text { siam/keprok, } \\
\text { pisang, sawo }\end{array}$ & $\begin{array}{l}\text { Kelapa } \\
\text { dalam, } \\
\text { Cengkeh, } \\
\text { kakao }\end{array}$ & Ayam daging \\
\hline Capkala & $\begin{array}{l}\text { Padi } \\
\text { sawah }\end{array}$ & - & $\begin{array}{l}\text { Pepaya, pisang, } \\
\text { sukun }\end{array}$ & - & $\begin{array}{l}\text { Ayam daging } \\
\text { dan itik }\end{array}$ \\
\hline $\begin{array}{l}\text { Sungai Raya } \\
\text { Kepulauan }\end{array}$ & Ubi kayu & $\begin{array}{l}\text { Sawi, lobak, } \\
\text { cabe besar, } \\
\text { ketimun, } \\
\text { semangka }\end{array}$ & Pisang & $\begin{array}{l}\text { Kelapa } \\
\text { dalam, } \\
\text { Cengkeh, } \\
\text { kakao }\end{array}$ & $\begin{array}{l}\text { Kuda dan } \\
\text { ayam daging }\end{array}$ \\
\hline Samalantan & $\begin{array}{l}\text { Kacang } \\
\text { tanah dan } \\
\text { kacang } \\
\text { hijau }\end{array}$ & Ketimun & $\begin{array}{l}\text { Jambu biji, } \\
\text { pepaya, sirsak }\end{array}$ & - & Ayam daging \\
\hline Monterado & - & $\begin{array}{l}\text { Kacang } \\
\text { panjang dan } \\
\text { terong }\end{array}$ & - & Kemiri & $\begin{array}{l}\text { Sapi, } \\
\text { kambing, } \\
\text { babi, itik }\end{array}$ \\
\hline $\begin{array}{l}\text { Lembah } \\
\text { Bawang }\end{array}$ & - & - & Pisang & - & Babi dan itik \\
\hline Bengkayang & - & - & - & Karet & Ayam daging \\
\hline Teriak & $\begin{array}{l}\text { Padi } \\
\text { ladang } \\
\text { dan ubi } \\
\text { kayu }\end{array}$ & $\begin{array}{l}\text { Cabe rawit, } \\
\text { terong, } \\
\text { kangkung }\end{array}$ & $\begin{array}{l}\text { Belimbing, } \\
\text { langsat/kokosa } \\
\text { n, jambu air, } \\
\text { jeruk besar, } \\
\text { manggis, } \\
\text { nangka, } \\
\text { pepaya, } \\
\text { rambutan, } \\
\text { salak }\end{array}$ & - & $\begin{array}{l}\text { Sapi, } \\
\text { kambing, } \\
\text { babi, itik }\end{array}$ \\
\hline Sungai Betung & $\begin{array}{l}\text { Ubi kayu, } \\
\text { ubi jalar, } \\
\text { kacang } \\
\text { tanah }\end{array}$ & - & - & $\begin{array}{l}\text { Karet dan } \\
\text { lada }\end{array}$ & $\begin{array}{l}\text { Sapi, } \\
\text { itik }\end{array}$ \\
\hline Ledo & Kedelai & $\begin{array}{l}\text { Cabe rawit dan } \\
\text { terong }\end{array}$ & $\begin{array}{l}\text { Belimbing, } \\
\text { Nenas, pepaya, } \\
\text { rambutan }\end{array}$ & $\begin{array}{l}\text { Kelapa } \\
\text { sawit }\end{array}$ & Babi \\
\hline
\end{tabular}




\begin{tabular}{|c|c|c|c|c|c|}
\hline \multirow{3}{*}{ Kecamatan } & \multicolumn{5}{|c|}{ Komoditas Pertanian Unggulan } \\
\hline & \multirow{2}{*}{$\begin{array}{c}\text { Tanaman } \\
\text { pangan }\end{array}$} & \multicolumn{2}{|c|}{ Hortikultura } & \multirow{2}{*}{ Perkebunan } & \multirow{2}{*}{ Peternakan } \\
\hline & & Sayuran & Buah-Buahan & & \\
\hline Suti Semarang & - & $\begin{array}{l}\text { Cabe rawit, } \\
\text { ketimun, } \\
\text { kangkung, } \\
\text { bayam }\end{array}$ & - & $\begin{array}{l}\text { Lada dan } \\
\text { kemiri }\end{array}$ & $\begin{array}{l}\text { Babi, ayam } \\
\text { buras, itik }\end{array}$ \\
\hline Lumar & - & Cabe rawit & $\begin{array}{l}\text { Jambu air dan } \\
\text { nenas }\end{array}$ & $\begin{array}{l}\text { Karet dan } \\
\text { lada }\end{array}$ & $\begin{array}{l}\text { Sapi, } \\
\text { kambing, } \\
\text { babi, ayam } \\
\text { buras, itik }\end{array}$ \\
\hline Sanggau Ledo & - & - & - & - & - \\
\hline Tujuh Belas & Kedelai & - & - & Lada & $\begin{array}{l}\text { Kambing dan } \\
\text { itik }\end{array}$ \\
\hline Seluas & Jagung & - & - & $\begin{array}{l}\text { Kelapa } \\
\text { sawit }\end{array}$ & Kambing \\
\hline Jagoi Babang & - & - & - & $\begin{array}{l}\text { Kelapa } \\
\text { sawit }\end{array}$ & $\begin{array}{l}\text { Sapi, } \\
\text { itik }\end{array}$ \\
\hline Siding & - & - & - & Lada & Itik \\
\hline
\end{tabular}

\section{Komoditas Unggulan Tanaman Pangan}

Komoditas pertanian tanaman pangan berdasarkan Badan Pusat Statistik (BPS) terdiri dari padi sawah, padi ladang, jagung, ubi kayu, ubi jalar, kacang tanah, kacang hijau, dan kedelai. Hampir semua komoditas tersebut dibudidayakan di Kabupaten Bengkayang. Padi ladang tidak dibudidayakan di Kecamatan Sungai Raya dan Sungai Raya Kepulauan. Di Kecamatan Sungai Raya juga tidak dibudidayakan komoditas ubi jalar dan kacang tanah, sedangkan di Kecamatan Samalantan juga tidak dibudidayakan kedelai. Semua komoditas tanaman pangan dibudidayakan di Kecamatan Jagoi Babang dan Siding yang merupakan wilayah perbatasan yang berbatasan langsung dengan Serawak, Malaysia.

Berdasarkan analisis Location Quotient (LQ) dan Shift Share Analysis (SSA) pada komoditas tanaman pangan, padi sawah merupakan komoditas unggulan tanaman pangan hanya di Kecamatan Capkala. Padi ladang merupakan komoditas unggulan tanaman pangan hanya di Kecamatan Teriak. Namun demikian, berdasarkan penelitian (Yustian, Sudadi, \& Ardiansyah, 2014), di Kabupaten Bengkayang padi sawah memiliki keunggulan kompetitif berdasarkan analisis Differential Shift (DS) dan Shift Share Analysis (SSA), sedangkan berdasarkan analisis Location Quotient (LQ) padi ladang merupakan memiliki keunggulan komparatif dan menjadi komoditas basis di Kabupaten Bengkayang. Di samping itu, secara historis Kabupaten Bengkayang merupakan salah satu dari 2 kabupaten di Kalimantan Barat yang memiliki hamparan sawah terluas dan menjadi lumbung padi di Kalimantan Barat.

Jagung merupakan komoditas unggulan tanaman pangan hanya di Kecamatan Seluas. Ubi kayu merupakan komoditas unggulan tanaman pangan di 3 kecamatan, yaitu Kecamatan Sungai Raya, Teriak, dan Sungai Betung. Ubi Jalar merupakan komoditas unggulan tanaman pangan hanya di Kecamatan Sungai Betung. Kacang tanah merupakan komoditas unggulan tanaman pangan di Kecamatan Samalantan dan Sungai Betung. Kacang hijau merupakan komoditas unggulan tanaman pangan hanya di Kecamatan Samalantan. Kedelai merupakan komoditas unggulan tanaman pangan di 4 kecamatan, yaitu Kecamatan Sungai Raya, Ledo, Tujuh Belas, dan Seluas. Wilayah perbatasan Kabupaten Bengkayang yang berbatasan langsung dengan Malaysia, yaitu Kecamatan Jagoi Babang dan Siding tidak memiliki komoditas unggulan tanaman pangan. 


\section{Komoditas Unggulan Tanaman Hortikultura}

Komoditas pada tanaman hortikultura dibedakan menjadi 2 kelompok komoditas, yaitu sayuran dan buah-buahan. Komoditas yang termasuk dalam kelompok sayuran terdiri dari 15 komoditas meliputi bawang daun, bawang merah, sawi, lobak, kacang panjang, cabe besar, cabe rawit, tomat, terong, buncis, ketimun, kangkung, bayam, labu siam, dan semangka. Sedangkan yang termasuk pada kelompok buah-buahan terdiri dari 23 komoditas, meliputi alpukat, belimbing, langsat/kokosan, durian, jambu biji, jambu air, jeruk siam/keprok, jeruk besar, mangga, manggis, nangka, nenas, pepaya, pisang, rambutan, salak, sawo, sirsak, sukun, melinjo, petai, markisa/konyal, dan jengkol.

\section{Komoditas Sayuran}

Komoditas sayuran yang dibudidayakan di wilayah perbatasan Kecamatan Jagoi Babang meliputi kacang panjang, cabe rawit, tomat, terong, ketimun, kangkung, bayam, dan semangka, sedangkan yang tidak dibudidayakan meliputi bawang daun, bawang merah, sawi, lobak, cabe besar, buncis, dan labu siyam. Di wilayah perbatasan Kecamatan Siding, komoditas sayur-sayuran yang dibudidayakan meliputi kacang panjang, cabe besar, cabe rawit, terong, ketimun, dan bayam, sedangkan yang tidak dibudidayakan meliputi bawang daun, bawang merah, sawi, lobak, tomat, buncis, kangkung, labu siyam, dan semangka.

Dari analisis LQ dan SSA pada komoditas sayuran, sawi dan lobak merupakan komoditas unggulan sayuran hanya di Kecamatan Sungai Raya Kepulauan. Kacang panjang merupakan komoditas unggulan sayuran di Kecamatan Sungai Raya dan Monterado. Cabe besar merupakan komoditas unggulan sayuran di Kecamatan Sungai Raya dan Sungai Raya Kepulauan. Cabe rawit merupakan komoditas unggulan sayuran di 4 kecamatan, yaitu Kecamatan Teriak, Ledo, Suti Semarang, dan Lumar.

Terong merupakan komoditas unggulan sayuran di 4 kecamatan, yaitu Kecamatan Sungai Raya, Monterado, Teriak, dan Ledo. Ketimun merupakan komoditas unggulan sayuran di 4 kecamatan, yaitu Kecamatan Sungai Raya, Sungai Raya Kepulauan, Samalantan, dan Suti Semarang. Kangkung merupakan komoditas unggulan sayuran di Kecamatan Teriak dan Suti Semarang. Bayam merupakan komoditas unggulan sayuran hanya di Kecamatan Suti Semarang. Semangka merupakan komoditas unggulan sayuran di Kecamatan Sungai Raya dan Sungai Raya Kepulauan.

Bawang daun, bawang merah tomat, buncis, dan labu siyam bukan merupakan komoditas unggulan sayuran di semua kecamatan, Kabupaten Bengkayang. Wilayah kecamatan yang berbatasan dengan Malaysia, yaitu Kecamatan Jagoi Babang dan Siding tidak memiliki komoditas unggulan sayuran.

\section{Komoditas Buah-Buahan}

Komoditas buah-buahan yang dibudidayakan di wilayah perbatasan Kecamatan Jagoi Babang meliputi belimbing, langsat/kokosan, durian, jambu biji, jambu air, jeruk siam/keprok, jeruk besar, mangga, manggis, nangka, nenas, pepaya, pisang, rambutan, sirsak, sukun, melinjo, petai, markisa/konyal, dan jengkol, sedangkan buah-buahan yang tidak dibudidayakan meliputi alpukat, salak, dan sawo. Di wilayah perbatasan Kecamatan Siding, komoditas buah-buahan yang dibudidayakan meliputi alpukat, belimbing, langsat/kokosan, durian, jambu biji, jambu air, mangga, manggis, nangka, nenas, pepaya, pisang, rambutan, salak, sirsak, sukun, petai, dan jengkol, sedangkan buah-buahan yang tidak dibudidayakan meliputi jeruk siam/keprok, jeruk besar, sawo, melinjo, dan markisa/konyal.

Dari analisis LQ dan SSA pada komoditas buah-buahan, belimbing merupakan komoditas unggulan buah-buahan di Kecamatan Teriak dan Ledo. Langsat atau kokosan merupakan komoditas unggulan buah-buahan hanya di Kecamatan Teriak. Jambu biji 
merupakan komoditas unggulan buah-buahan hanya di Kecamatan Samalantan. Jambu air merupakan komoditas unggulan buah-buahan di Kecamatan Teriak dan Lumar.

Jeruk siam atau keprok merupakan komoditas unggulan buah-buahan hanya di Kecamatan Sungai Raya. Jeruk besar merupakan komoditas unggulan buah-buahan hanya di Kecamatan Teriak. Manggis merupakan komoditas unggulan buah-buahan hanya di Kecamatan Teriak. Nangka merupakan komoditas unggulan buah-buahan hanya di Kecamatan Teriak. Nenas merupakan komoditas unggulan buah-buahan di Kecamatan Ledo dan Lumar. Pepaya merupakan komoditas unggulan buah-buahan di 4 kecamatan, yaitu Kecamatan Capkala, Samalantan, Teriak, dan Ledo. Pisang merupakan komoditas unggulan buah-buahan di 4 kecamatan, yaitu Kecamatan Sungai Raya, Capkala, Sungai Raya Kepulauan, dan Lembah Bawang.

Rambutan merupakan komoditas unggulan buah-buahan di Kecamatan Teriak dan Ledo. Salak merupakan komoditas unggulan buah-buahan hanya di Kecamatan Teriak. Sawo merupakan komoditas unggulan buah-buahan hanya di Kecamatan Sungai Raya. Sirsak merupakan komoditas unggulan buah-buahan hanya di Kecamatan Samalantan. Sukun merupakan komoditas unggulan buah-buahan hanya di Kecamatan Capkala.

Alpukat, durian, mangga, melinjo, petai, markisa atau konyal, dan jengkol bukan merupakan komoditas unggulan buah-buahan di semua kecamatan, Kabupaten Bengkayang. Wilayah Kecamatan Jagoi Babang dan Siding yang merupakan wilayah perbatasan yang berbatasan langsung dengan Malaysia tidak memiliki komoditas ungggulan buah-buahan. Dengan kata lain, di wilayah perbatasan Kecamatan Jagoi Babang dan Siding yang berbatasan dengan Malaysia tidak memiliki komoditas unggulan tanaman hortikultura (sayuran dan buah-buahan).

\section{Komoditas Unggulan Tanaman Perkebunan}

Komoditas pertanian tanaman perkebunan terdiri dari 10 komoditas, meliputi komoditas karet, kelapa dalam, kelapa hibrida, kopi, cengkeh, lada, kakao, kelapa sawit, kemiri, dan pinang. Di Kecamatan Jagoi Babang yang merupakan wilayah yang berbatasan dengan Malaysia, komoditas perkebunan yang dibudidayakan meliputi karet, kelapa dalam, kelapa hibrida, kelapa sawit, lada, kakao, dan kemiri, sedangkan komoditas perkebunan yang tidak dibudidayakan kopi, cengkeh dan pinang. Di Kecamatan Siding yang juga merupakan wilayah perbatasan, komoditas perkebunan yang dibudidayakan adalah karet, lada, kakao, dan kemiri, sedangkan komoditas perkebunan yang tidak dibudidayakan meliputi kelapa dalam, kelapa hibrida, kelapa sawit, kopi, cengkeh, dan pinang.

Berdasarkan analisis LQ dan SSA komoditas tanaman perkebunan, karet merupakan komoditas unggulan perkebunan di Kecamatan Bengkayang, Sungai Betung, dan Lumar. Kelapa dalam merupakan komoditas unggulan perkebunan di Kecamatan Sungai Raya dan Sungai Raya Kepulauan. Kelapa sawit merupakan komoditas unggulan perkebunan di Kecamatan Ledo, Seluas, dan Jagoi Babang.

Cengkeh merupakan komoditas unggulan perkebunan di Kecamatan Sungai Raya dan Sungai Raya Kepulauan. Lada merupakan komoditas unggulan perkebunan di 5 kecamatan, yaitu Kecamatan Sungai Betung, Suti Semarang, Lumar, Tujuh Belas, dan Siding. Kakao merupakan komoditas unggulan perkebunan di Kecamatan Sungai Raya, Capkala, dan Sungai Raya Kepulauan. Kemiri merupakan komoditas unggulan perkebunan hanya di Kecamatan Suti Semarang.

Kelapa hibrida, kopi, dan pinang bukan merupakan komoditas unggulan perkebunan di semua kecamatan, Kabupaten Bengkayang. Di Kecamatan Jagoi Babang yang merupakan wilayah perbatasan yang berbatasan langsung dengan Malaysia memiliki komoditas unggulan perkebunan yaitu kelapa sawit. Sedangkan di Kecamatan Siding yang juga berbatasan langsung dengan Malaysia juga memiliki komoditas unggulan perkebunan yaitu lada. Dengan kata lain, Kecamatan Jagoi Babang dan Siding yang merupakan 
wilayah perbatasan yang berbatasan langsung dengan Malaysia memiliki komoditas unggulan tanaman perkebunan. Menurut (Hidayat, 2013), komoditas kelapa sawit memiliki keunggulan kompetitif dengan peningkatan pertumbuhan produksi berdasarkan analisis Shift Share Klasik dan Shift Share Modifikasi Esteban-Marquillas, sedangkan lada menjadi komoditas unggulan atau basis pada sub sektor perkebunan di Kabupaten Bengkayang berdasarkan analisis LQ. Hal ini didukung oleh penelitian (Burhansyah, 2017), lada merupakan komoditas unggulan sub sektor perkebunan di Kabupaten Bengkayang.

\section{Komoditas Unggulan Peternakan}

Komoditas peternakan terdiri dari 8 komoditas ternak meliputi sapi, kuda, kambing, babi, ayam buras, ayam daging, ayam petelur, dan itik. Di wilayah perbatasan Kecamatan Jagoi Babang, ternak yang dibudidayakan meliputi ternak sapi, kambing, babi, ayam buras, ayam daging, dan itik, sedangkan ternak yang tidak dibudidayakan meliputi kuda dan ayam petelur. Di wilayah perbatasan Kecamatan Siding ternak yang dibudidayakan meliputi sapi, kambing, babi, ayam buras, dan itik, sedangkan ternak yang tidak dibudidayakan adalah kuda, ayam daging, dan ayam petelur.

Berdasarkan analisis LQ dan SSA pada komoditas peternakan, ternak sapi merupakan komoditas unggulan peternakan di 5 kecamatan, yaitu Kecamatan Monterado, Teriak, Sungai Betung, Lumar, dan Jagoi Babang. Kuda merupakan komoditas unggulan peternakan hanya di Kecamatan Sungai Raya Kepulauan. Kambing merupakan komoditas unggulan peternakan di 5 kecamatan, yaitu Kecamatan Monterado, Teriak, Lumar, Tujuh Belas, dan Seluas. Menurut (Burhansyah, 2017), kambing merupakan komoditas unggulan sub sektor peternakan di Kabupaten Bengkayang.

Babi merupakan komoditas unggulan peternakan di 8 kecamatan, yaitu Kecamatan Monterado, Lembah Bawang, Teriak, Sungai Betung, Ledo, Suti Semarang, Lumar, dan Jagoi Babang. Ayam buras merupakan komoditas unggulan peternakan di Kecamatan Monterado, Suti Semarang, dan Lumar. Ayam daging merupakan komoditas unggulan peternakan di 5 kecamatan, yaitu Kecamatan Sungai Raya, Capkala, Sungai Raya Kepulauan, Samalantan, dan Bengkayang.

Ayam petelur bukan merupakan komoditas unggulan peternakan di semua kecamatan, Kabupaten Bengkayang. Kecamatan Jagoi Babang yang berbatasan dengan Malaysia memiliki 3 komoditas unggulan peternakan, yaitu sapi, babi, dan itik. Kecamatan Siding yang juga berbatasan dengan Malaysia hanya memiliki 1 komoditas unggulan peternakan, yaitu itik. Dengan kata lain, Kecamatan Jagoi Babang dan Siding yang merupakan wilayah perbatasan yang berbatasan langsung dengan Malaysia memiliki komoditas unggulan peternakan.

\section{KESIMPULAN}

Komoditas pertanian unggulan di wilayah perbatasan Kabupaten Bengkayang, khususnya di Kecamatan Jagoi Babang yang berbatasan langsung dengan Serawak, Malaysia adalah kelapa sawit pada sektor perkebunan dan sapi, babi, serta itik pada sektor peternakan. Komoditas pertanian unggulan di Kecamatan Siding yang juga berbatasan langsung dengan negara tetangga adalah lada pada sektor perkebunan dan itik pada sektor peternakan. Dalam mendukung pengembangan lumbung pangan nasional, pengembangan komoditas pertanian di wilayah perbatasan tepatnya di Kecamatan Jagoi Babang dan Siding diprioritaskan pada komoditas pertanian unggulan yang dimiliki oleh wilayah tersebut, yaitu kelapa sawit, lada, sapi, babi, dan itik. 


\section{UCAPAN TERIMA KASIH}

Penulis menyampaikan ucapan terima kasih kepada Dr. Ir. Trip Alihamsyah yang telah memberikan bimbingan, arahan serta masukan-masukannya untuk perbaikan makalah ini. Ucapan terima kasih juga disampaikan kepada berbagai pihak yang telah memberikan kontribusinya dalam penulisan makalah ini.

\section{DAFTAR PUSTAKA}

Abdurahman, A., Dariah, A., \& Mulyani, A. (2008). Strategi dan Teknologi Pengelolaan Lahan Kering Mendukung Pengadaan Pangan Nasional. Jurnal Litbang Pertanian, 27(2), 43-49.

BPS Kabupaten Bengkayang. (2016). Kabupaten Bengkayang Dalam Angka 2016. Bengkayang.

Burhansyah, R. (2017). Inventory and Identification of Specific Locations Technology Needs of Agriculture Superior Comodities in West Kalimantan. Jurnal Pertanian Agros, 19(1), 61-76.

Gabriel, D. S., Nurcahyo, R., Muslim, E., \& Sumaedi, S. (2016). Perancangan Peta Jalan Pengembangan Industri Hasil Pertanian pada Wilayah Kabupaten dengan Metode VRISA dan Rantai Nilai. Jurnal Manajemen Teknologi, 13(1), 53-63.

Hidayat, R. (2013). Analisis Komoditas Unggulan Sub Sektor Perkebunan di Kabupaten Bengkayang Provinsi Kalimantan Barat. Jurnal Social Economic of Agriculture, 2(1), 54-66.

Kementerian Pertanian Republik Indonesia. (2017). Membangun Lumbung Pangan di Perbatasan: Sinergitas Merintis Ekspor Pangan di Wilayah Perbatasan NKRI.

Koirala, K. H., Mishra, A., \& Mohanty, S. (2016). Impact of Land Ownership on Productivity and Efficiency of Rice Farmers: The Case of the Philippines. Land Use Policy, 50, 371-378.

Mulyani, A., \& Sarwani, M. (2013). Karakteristik dan Potensi Lahan Sub Optimal untuk Pengembangan Pertanian di Indonesia. Jurnal Sumberdaya Lahan, 7(1), 47-55.

Mulyono, J., Hadi, S., \& Munibah, K. (2016). Improved Profits and Wetland Paddy Farming Scale as the Leading Commodity in Agroecological Zones. Jurnal Ekonomi Pembangunan: Kajian Masalah Ekonomi dan Pembangunan, 17(1), 15-27.

Mulyono, J., \& Munibah, K. (2016a). Pendekatan Location Quotient dan Shift Share Analysis dalam Penentuan Komoditas Unggulan Tanaman Pangan di Kabupaten Bantul. Jurnal Informatika Pertanian, 25(2), 221-230.

Mulyono, J., \& Munibah, K. (2016b). Strategi Pembangunan Pertanian di Kabupaten Bantul dengan Pendekatan A'WOT. Jurnal Pengkajian dan Pengembangan Teknologi Pertanian, 19(3), 199-211.

Priyanto, D., \& Diwyanto, K. (2014). Pengembangan Pertanian Wilayah Perbatasan Nusa Tenggara Timur dan Republik Demokrasi Timor Leste. Jurnal Pengembangan Inovasi Pertanian, 7(4), 207-220.

Purwaningsih, Y. (2008). Ketahanan Pangan: Situasi, Permasalahan, Kebijakan, dan Pemberdayaan Masyarakat. Jurnal Ekonomi Pembangunan, 9(1), 1-27.

Putra, A. (2015). Hubungan Kerjasama Perbatasan Indonesia-Malaysia (Studi Kasus Perbatasan NunukanTawau). Jurnal Hukum IUS QUIA IUSTUM, 22(2), 308-326.

Raharjo, S. N. I. (2013). Kebijakan Pengelolaan Kawasan Perbatasan Darat Indonesia-Malaysia (Studi Evaluatif di Kecamatan Entikong). Jurnal Widyariset, 16(1), 71-80.

Sukmawani, R., Haeruman, M., Sulistyowati, L., \& Perdana, T. (2014). Model Pengembangan Pepaya Sebagai Komoditas Unggulan Lokal yang Berdaya Saing. Jurnal Ekonomi Pembangunan: Kajian Masalah Ekonomi dan Pembangunan, 15(2), 128-140.

Yustian, Sudadi, U., \& Ardiansyah, M. (2014). Arahan dan Strategi Pengembangan Lahan Sawah di Wilayah Pesisir Provinsi Kalimantan Barat. Jurnal Ilmu Tanah dan Lingkungan, 16(1), 31-37. 
